\title{
Influence of epicentral distance on local seismic response in Kolkata City, India
}

\author{
William K Mohanti ${ }^{1, *}$, Akhilesh K Verma ${ }^{1}$, Franco Vaccari ${ }^{2,3}$ and Giuliano F Panza Fin $^{2,3,4}$ \\ ${ }^{1}$ Department of Geology and Geophysics, Indian Institute of Technology, Kharagpur 721 302, India. \\ ${ }^{2}$ Department of Mathematics and Geosciences, University of Trieste, Trieste, Italy. \\ ${ }^{3}$ Earth System Physics Section/Sand Group, The Abdus Salam International Centre for \\ Theoretical Physics, Trieste, Italy. \\ ${ }^{4}$ Institute of Geophysics, China Earthquake Administration (CEA), Beijing, China. \\ ${ }^{*}$ Corresponding author.e-mail: wkmohanty@gg.iitkgp.ernet.in
}

The influence of source and epicentral distance on the local seismic response in the Kolkata city is investigated by computing the seismic ground motion along 2-D geological cross-sections in the Kolkata city for the earthquake that occurred on 12 June $1897\left(M_{w}=8.1\right.$; focal mechanism: dip $=57^{\circ}$, strike $=$ $110^{\circ}$ and rake $=76^{\circ}$; focal depth $=9 \mathrm{~km}$ ) in Shillong plateau. For the estimation of ground motion parameters, a hybrid technique is used, which is the combination of modal summation and finite difference method. This technique allows the estimation of site specific ground motion for various events located at different distances from Kolkata city, taking into account simultaneously the position and geometry of the seismic source, the mechanical properties of the propagation medium and the geotechnical properties of the site. The epicenter of the Shillong earthquake is about $460 \mathrm{~km}$ away from Kolkata. The estimated peak ground acceleration (PGA) varies in the range of $0.11-0.18 \mathrm{~g}$ and this range corresponds to the intensity of IX to X on the Mercalli-Cancani-Sieberg (MCS) scale and VIII on the Modified Mercalli (MM) scale. The maximum amplification in terms of response spectral ratio (RSR) varies from 10 to 12 in the frequency range 1.0-1.5 Hz. These amplifications occur in correspondence to low-velocity shallow, loose soil deposit. The comparison of these results with earlier ones obtained considering the Calcutta earthquake that occurred on 15 April $1964\left(M_{w}=6.5\right.$; focal mechanism: dip $=32^{\circ}$, strike $=232^{\circ}$ and rake $=56^{\circ}$; focal depth $=36 \mathrm{~km}$ ) shows that the source parameters (magnitude and focal mechanism) and epicentral distance play an important role on site response but the variation in the frequency of the peak values (RSR) is negligible. The obtained results match with observed reported intensities in Kolkata region.

\section{Introduction}

Kolkata, the capital of West Bengal state, is one of the oldest industrial cities in India and it has attained the population of about 13 million (Census 2001, http://www.censusindia.gov.in/). The rapid increase in population density and industrial developments across the city has increased the seismic risk, and therefore it is important to assess the seismic hazard of the city for civil engineers and city planner to construct new and retrofit the old buildings. This metropolitan city lies between latitude $22^{\circ} 20^{\prime} \mathrm{N}$ to $23^{\circ} 00^{\prime} \mathrm{N}$ and longitude $88^{\circ} 04^{\prime} \mathrm{E}$ to $88^{\circ} 33^{\prime} \mathrm{E}$ in the eastern part of India. Kolkata is very close to the plate boundary zone (northeast and Indo-Burma ranges) of India, which is

Keywords. Kolkata city; response spectral ratio (RSR); peak ground acceleration (PGA); seismic sources; hybrid technique. 
one of the seismically most active regions of the world. As per the Seismic Zonation Map of India, Kolkata lies at the boundary of Indian seismic zones III and IV. The expected ground motion for these zones ranges $0.20-0.25$ g (IS: 1893 (Part 1): 2002). A recent study by Mohanty and Walling (2008a) suggests that most of Kolkata lies in zone IV. The city and its environ have been and will be affected by near as well as far earthquakes from Assam Seismic Gap, Shillong Plateau, IndoBurma ranges, Andaman-Nicobar Island and the whole NE Himalayan. The distant earthquakes that shook Kolkata include the 1 September 1803; 26 August 1833; 31 December 1881; 12 June 1897; 15 January 1934 and the 15 August 1950 Assam earthquake. Two near events that have been strongly felt in Kolkata are the 29 September 1906 and 15 April 1964 earthquakes. Earthquakes have shaken most of the megacities in India, such as Delhi, Kolkata, Mumbai, Bangalore and Chennai, numerous times in the past 200 years. Among these, Delhi and Kolkata have experienced maximum shaking as cumulative number of events per year (Martin and Szeliga 2010). Kolkata and Delhi show the shortest interval between shaking at a given intensity due to their tectonic setting. In these cities, the intensity V (MSK-64/EMS98 scale) occurs every 15 years approximately (Martin and Szeliga 2010). Any macroseismic intensity scale by its nature is a discrete sequence of integer values and half-integer epicentral intensity values formally do not belong to any intensity scale. Therefore, to be conservative, we rounded off by excess the non-integer values given in the literature.

Along the Kolkata-Krishnanagar line, the basement depth varies from 7 to $10 \mathrm{~km}$. For a given earthquake magnitude, the ground response varies in different locations of Kolkata. Alluvial deposits (alternating layers of sand and clay) of Gangetic Delta form the upper soil in Kolkata. Usually the younger softer soils amplify the ground motion relative to older more competent soils or bedrock at particular frequencies due to the higher acoustic impedance contrast with the underlying hard deposits. Thick Holocene alluvium plays a great role in the amplification of ground motion as well as earthquake related failure like liquefaction, large ground deformation and lateral spreading.

The site response is the local ground response; it includes basin effects and the influence of surface topography. 'Local ground response' represents essentially the influence of relatively shallow geology on the propagating waves and these effects can be satisfactorily modelled using 2-D geological profiles. Several site response studies with special attention towards microzonation have already been carried out for metropolitan cities in India like Delhi (Parvez et al. 2004, 2006; Mohanty et al. 2007), Sikkim (Nath 2004), Jabalpur (Mishra 2004), Haldia (Mohanty and Walling 2008b), Talchir (Mohanty et al. 2009; Walling and Mohanty 2009), and all show that the response of a given site is not invariant with respect to changes in the earthquake source properties and its epicentral distance, as clearly proven by straightforward application of basic theory (e.g., Field et al. 2000; Panza et al. 2001). These variations depend upon many factors such as source mechanism (SM), epicentral distance (ED), focal depth (FD), geological condition (GC) or variation along energy transmission path, magnitude (M), soil condition (SC) at the vicinity of the site, damping ratio (DR) and period (T). Thus, according to Clough and Pension (1993), the response spectra for earthquake ground motion is a multispace non-linear function with the form:

$$
\mathrm{S}=\mathrm{S}(\mathrm{SM}, \mathrm{ED}, \mathrm{FD}, \mathrm{GC}, \mathrm{M}, \mathrm{SC}, \mathrm{DR}, \mathrm{T})
$$

The effects of ED, FD, M and SC on response spectra are usually taken into consideration while specifying the intensity levels of the design response spectra. But the effects of SM and GC on the response spectra are not well understood; therefore, such effects cannot be quantified when defining response spectra for design purposes. The separation of the effects of magnitude, distance, style of the faulting, tectonic feature and site conditions on the ground response is an important task and should be considered in the seismic hazard analysis at a given site, although the boundaries between source, path and site related factors are not always clear, due to the non-linearity of the relation between them. The ground motion variability could be reduced by eliminating the eventspecific or site-specific contribution to the ground motion amplitudes (Strasser and Bommer 2009a), but very often, this is 'mission impossible' (Panza et al. 2011). The empirical data are unlikely to capture the full variability of source parameter combinations, even in the case of a single source. On the other side, realistic numerical simulations permit a physically sound analysis of the influence of source parameter variability on ground motion and allow the control of site locations, and thus ground motions can be computed on a properly dense grid. Nowadays the perception of the maximum physically possible ground motion may gradually become more influenced by prediction of well-constrained theoretical models than by empirical models, since there is still no guarantee on the variability associated with observed ground motion (Strasser and Bommer 2009b). The acceleration varies from component to component and it has 
also been reported that the high value of the vertical component is due to large objects being thrown in the air during earthquakes (e.g., Brune 1970; Hanks and Johnson 1976). A study by Oldham (1899) interprets the high value of vertical acceleration in excess of gravity in which the large boulders were thrown out of their sockets without disturbing the surrounding soil during the 1897 Shillong earthquake. It has also been shown that PGA is not a good indicator of the overall level of shaking and related damage (Uang and Bertero 1990; Decanini and Mollaioli 1998; Panza et al. 2001, 2003; Bommer et al. 2002). Mohraz (1978) describes the influence of earthquake magnitude on response amplification for alluvium. The study showed larger amplification of acceleration for records with magnitudes between 6 and 7 than for those with magnitudes between 5 and 6 . While the study used a limited number of records and no specific recommendation was made, it shows that earthquake magnitude can influence spectral shapes in a nonlinear way, and this fact may need to be considered when developing design spectra for a specific site, particularly for critical structures.

The argument to study seismic response in Kolkata city due to far distant earthquakes (1897, Shillong earthquake in this study) is very essential for looking at the effects of distant earthquakes in the recent times. In this context, a recent study by Bhattacharya et al. (2011) supports the present objective where it has been reported that Katno (Tokyo) area in Japan was strongly affected by an earthquake occurred at a distance of $\sim 450 \mathrm{~km}$. In this study, we simulate the seismic ground motion along a 2-D geological cross-section in Kolkata city for a seismic source in Shillong plateau (i.e., Shillong earthquake of 1897 located at $\sim 460 \mathrm{~km}$ from Kolkata). Ground motion parameter are estimated using a hybrid technique (Fäh et al. 1993, 1994; Panza et al. 2001), which is the combination of modal summation (Panza 1985; Florsch et al. 1991; Panza et al. 2001) and finite difference method (Alterman and Karal 1968; Boore 1972; Kelly et al. 1976; Virieux 1984, 1986; Levander 1988). This technique takes into account simultaneously the position and geometry of the seismic source, the mechanical properties of the propagation medium and the geotechnical properties of the site. In the computation, we consider the earthquake of 12 June 1897, Shillong earthquake, $M_{w}=8.1$; focal mechanism: $\operatorname{dip}=57^{\circ}$, strike $=$ $110^{\circ}$ and rake $=76^{\circ}$; focal depth $=9 \mathrm{~km}$ (Bilham and England 2001), located at a distance of about $460 \mathrm{~km}$ from Kolkata. Then, comparative analysis is made of the results obtained in this computation with earlier ones (Vaccari et al. 2011) obtained considering the Calcutta earthquake that occurred on 15 April 1964, $M_{w}=6.5$; focal mechanism: dip $=32^{\circ}$, strike $=232^{\circ}$ and rake $=56^{\circ}$; focal depth $=36 \mathrm{~km}$ (GSI 2000; Chandra 1977). In this paper the local seismic response in Kolkata city is analysed for two earthquake scenarios with different source mechanisms, one located near to Bay of Bengal and the other in the Shillong plateau. Further, the effect of epicentral distance is analysed keeping source parameters fixed and equal to those of the Shillong earthquake. The adopted method is innovative and at the same time a well-established one and has been employed in several site response studies worldwide (e.g., Fäh et al. 1994; Fäh and Panza 1994; Panza et al. 2002; Ding et al. 2004; Parvez et al. 2003, 2006; Zuccolo et al. 2008).

\section{Geology and seismo-tectonic setting of the study area}

Kolkata lies over the Bengal basin (figure 1). Thick alluvial deposits of the Gangetic Delta - the world's largest delta - comprising alternate layers of sand and clay, form the soil over which the study region lies (Gobindraju and Bhattacharya 2012). The thickness of the sediments increases towards south and east to more than $16 \mathrm{~km}$, i.e., the deepest part in the West Bengal basin (Curray and Moore 1971; Murphy 1988), and finally attains the thickness of $20 \mathrm{~km}$ underneath Bangladesh (Nandy 2001). The Mesozoic and Tertiary rocks are exposed in the folded flank of Bengal basin and the Permo-Carboniferous Gondwana coals are the oldest Phanerozoic sediments at the holes drilled into the Precambrian Indian platform tectonic zone in northwest Bengal basin. These intracratonic, faultbounded Gondwana coal deposits are exposed at the western fringe of the Bengal basin, in Bihar state of India (Khan and Muminullah 1980).

Kolkata lies over a sedimentary deposit about $7 \mathrm{~km}$ thick, above the crystalline basement (Murty et al. 2008). In the depositional sequence the top $0.35-0.45 \mathrm{~km}$ is Quaternary followed by $4.5-$ $5.5 \mathrm{~km}$ of Tertiary sediments, $0.5-0.7 \mathrm{~km}$ of Cretaceous Trap and $0.6-0.8 \mathrm{~km}$ of Permo-carboniferous Gondwana rocks. There is a huge impedance contrast (i.e., very sharp increase in S-wave velocity) at very shallow depth (at the boundary between 2-D and 1-D structural model in this study), which agrees closely with the model given by Mitra et al. (2008) (see figures 2 and 3).

Tectonically, the Bengal basin can be grossly subdivided as follows: (1) the western 'stable shelf' region (also named 'Indian platform'), underlain by Precambrian continental crust, (2) the central deep basin, and (3) the eastern ChittagongTripura fold belt. The Eocene Hinge Zone (EHZ) 


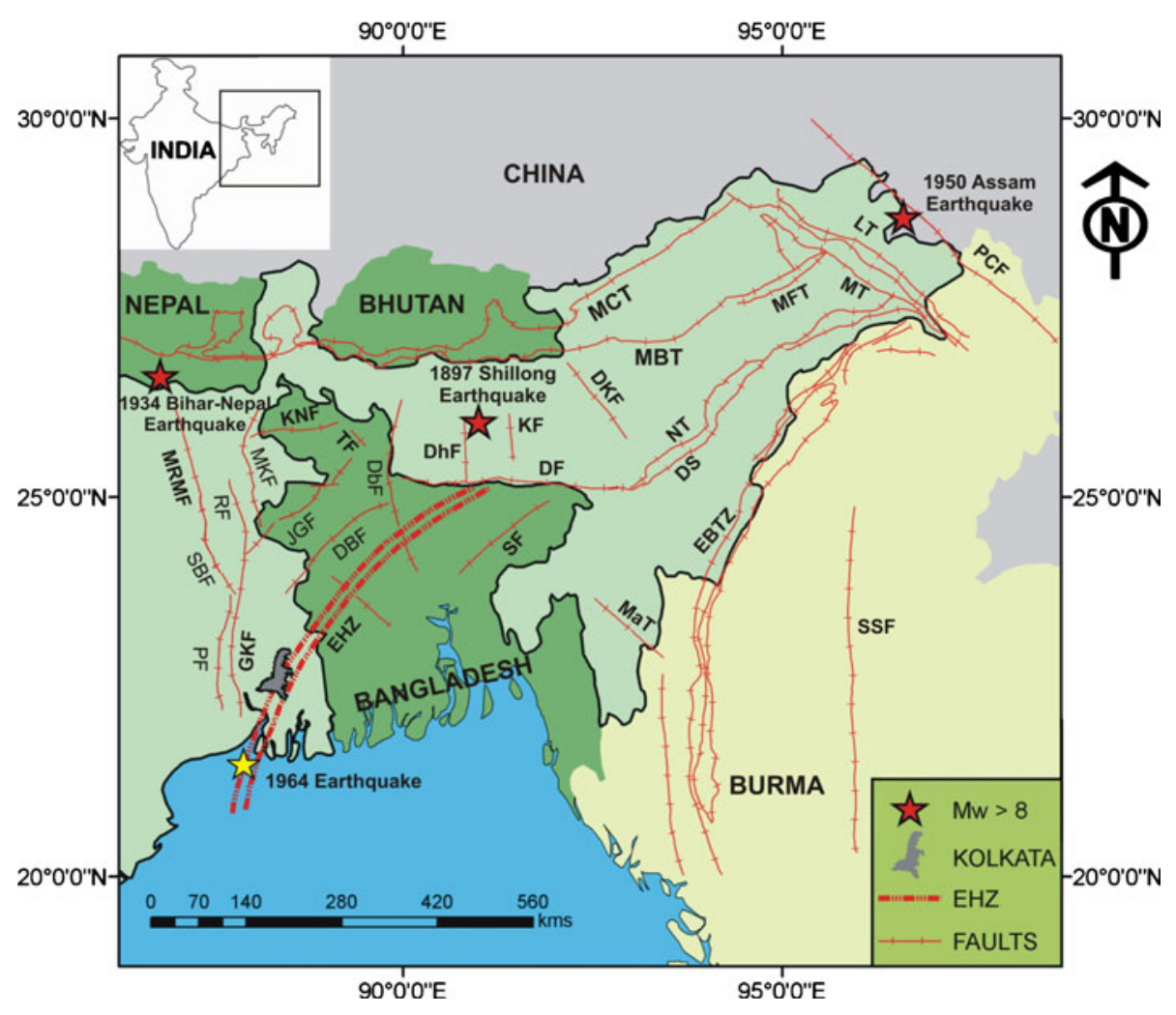

Figure 1. Tectonic setting of Kolkata, Bengal basin and its surroundings. MKF: Malda-Kishanganj Fault; DbF: Dhubri Fault; JGF: Jangipur-Gaibandha Fault; RF: Rajmahal Fault; SBF: Sainthia Bahmani Fault; GKF: GarhmaynaKhandaghosh Fault; DBF: Debagram-Bogra Fault; PF: Pingla Fault; EHZ: Eocene Hinge Zone; MCT: Main Central Thrust; MBT: Main Boundary Thrust; MFT: Main Frontal Thrust; PCF: Po Chu Fault; NT: Naga Thrust; DT: Disang Thrust; DF: Dauki Fault; KF: Kulsi Fault; DhF: Dudhnoi Fault; SF: Sylhet Fault; LT: Lohit Thrust; DKF: Dhansiri Kopili Fault; MT: Mishmi Thrust; KNF: Katihar-Nailphamari Fault; TF: Tista Fault; MaT: Mat Fault; SSF: Shan-Shagaing Fault; EBTZ: Eastern Boundary Thrust Zone; MRMF: Munger-Saharsha Ridge Marginal Fault (modified after GSI 2000; after Vaccari et al. 2011). The square box (inset) shows the location of the Bengal basin and its surrounding region in the Indian context.

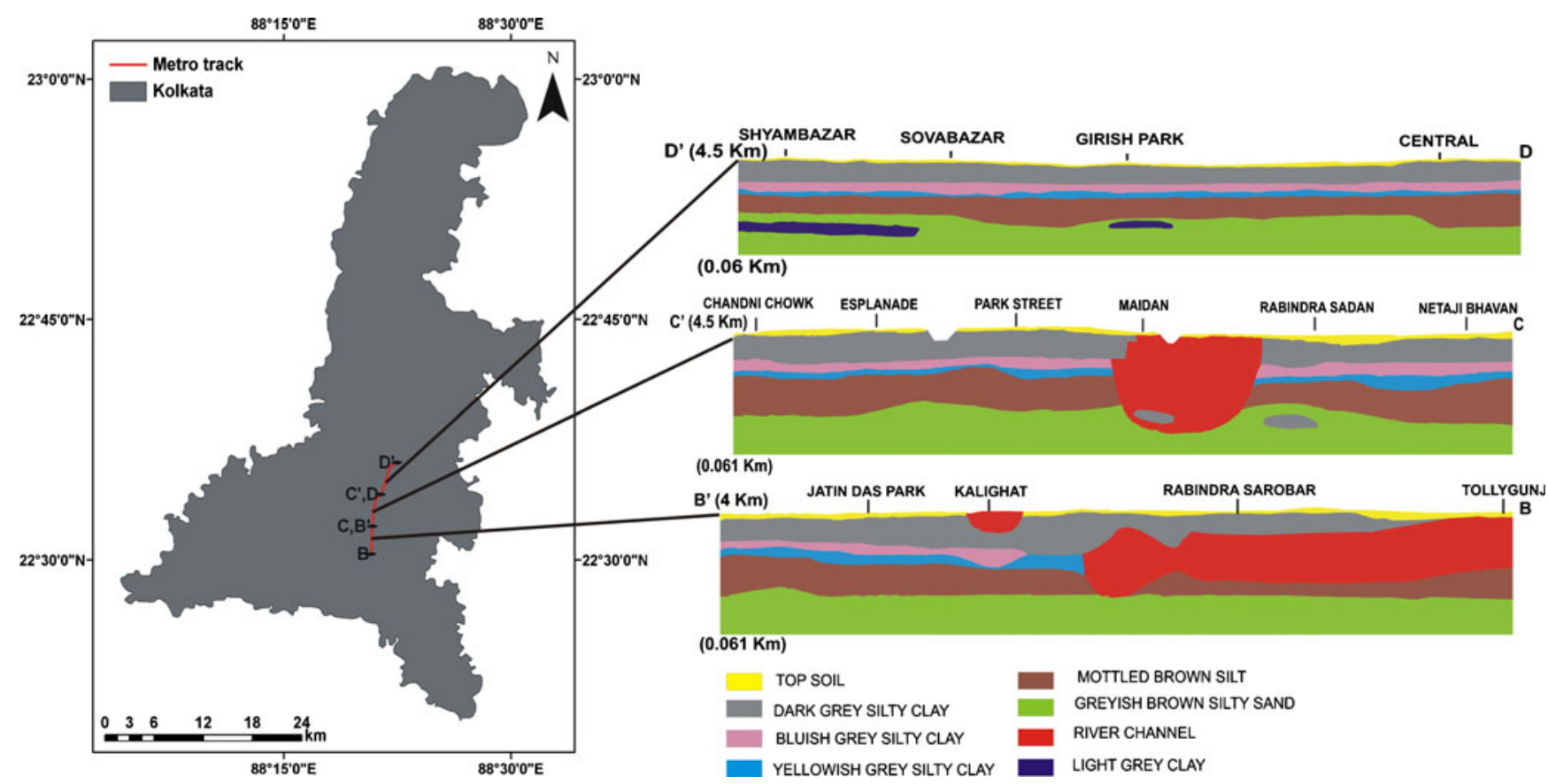

Figure 2. 2-D Geological cross-sections $\mathrm{BB}^{\prime}, \mathrm{CC}^{\prime}$ and $\mathrm{DD}^{\prime}$ run from Tollygunj to Shyam Bazar in Kolkata city. The numbers at the left top and bottom are the length and depth of the respective profiles. 

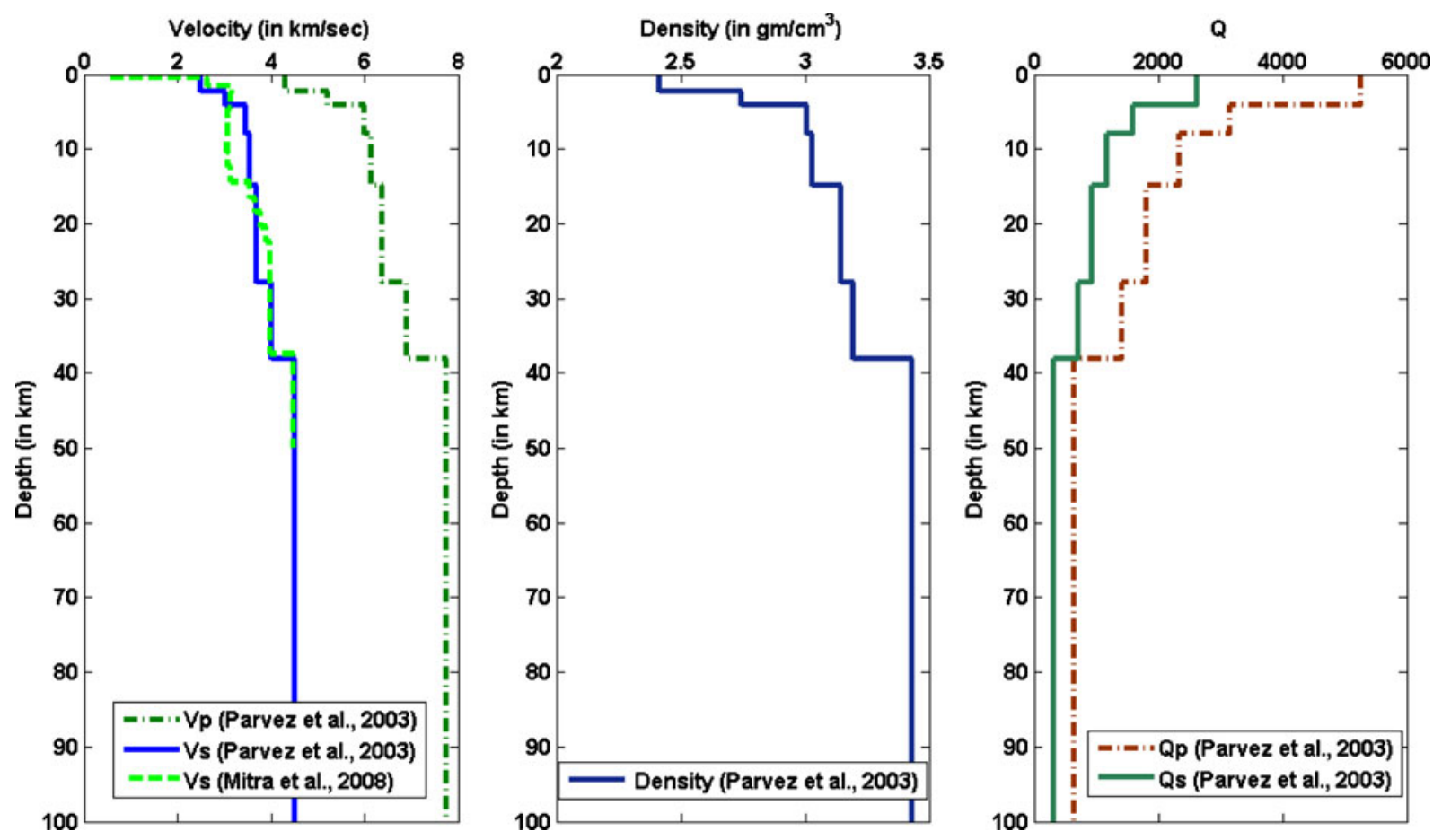

Figure 3. Regional structural reference model for the study area. Variations of seismic velocities (i.e., Vp and Vs), density and Q with depth after Parvez et al. (2003).

separates the stable shelf region from the central deep basin (Sengupta 1966). The narrow $(25-100 \mathrm{~km}) \mathrm{EHZ}$ is also known as the 'CalcuttaMymensingh gravity high' (Sengupta 1966; Khandoker 1989), although more recent data (Khan and Agarwal 1993) suggest that this term is somewhat misleading. The hinge zone runs in a NE-SW direction (figure 1) between the NagaHaflong-Disang thrust (NT) zone or Dauki fault (DF), at the southern boundary of the Shillong Plateau of Assam in the northeast, to the Indian part of the Bay of Bengal, off the east coast of India to the south (figure 1). The other major fault systems of the basin are the Garhmayna-Khanda Ghosh Fault (GKF), Jangipur-Gaibandha Fault (JGF), Pingla Fault (PF), Sainthia-Bahmani Fault (SBF), Malda-Kishanganj Fault (MKF), Rajmahal Fault (RF) and Debagram-Bogra Fault (DBF) (figure 1). The EHZ is a regional feature that demarcates the continent-ocean transition beneath the Bengal Fan and divides, tectonically, the Bengal basin into two major units: the shelf and the geosynclinal area. The EHZ demarcates a zone of differential thickening and subsidence rate of the overlying Oligocene and Miocene section (Salt et al. 1986). In West Bengal, the hinge is cut across by numerous en-echelon faults and by moderate flexures. From the seismic prospecting records, across the EHZ, there is a sharp change in facies and pressure regime in the Upper Paleogene and Neogene sections (Ganguly 1997).

\section{Seismicity of the study area}

The seismic hazard around Kolkata city is moderate to high, according to the seismic zonation map of India. The region lies in the expected PGA range from 0.2 to $0.25 \mathrm{~g}$ that corresponds to the seismic zones III and IV (IS: 1893 (Part 1): 2002). Although Kolkata historical record does not report any destructive earthquake inside the city, it has been strongly affected by near as well as far earthquakes. Two near source events are known to have caused considerable damage to Kolkata: the 29 September 1906 with intensity VI, in Modified Mercalli (MM) scale, VII as per RossiForel scale (Middlemiss 1908) or Mercalli-CancaniSieberg (MCS) scale (Decanini et al. 1995) at Kolkata and the 15 April 1964 earthquake (source at $100 \mathrm{~km}$ south of Kolkata) with reported damage intensity of VI (MCS) surrounding Kolkata (Jhingran et al. 1969). The far source earthquakes that have recorded history of damage in Kolkata are the 23 March 1839 (Burma), the 10 January 1869 (Cachar, Assam; Oldham 1883), the 31 December 1881 Nicobar earthquake, the 12 June 1897 Shillong earthquake, the Srimangal 
earthquake of 8 July 1918 that generated intensity V (isoseismal 5 in Oldham scale, Stuart 1926) and the Bihar-Nepal earthquake (source at $480 \mathrm{~km}$ from Kolkata, towards $\mathrm{N} 20^{\circ} \mathrm{W}$ ) of 15 January 1934 (intensity VII (MCS) Dunn et al. 1939). Among these, the most notable earthquake is the Shillong earthquake of 12 June 1897, $M_{w}=8.1$ (Bilham and England 2001), epicenter at about $470 \mathrm{~km}$ towards $\mathrm{N} 35^{\circ} \mathrm{E}$ from Kolkata, that gave rise to damage of intensity (MSK-64/EMS-98) of VII (isoseismal 3 in Oldham scale, Oldham 1899) and VIII in MM scale (Seeber and Armbruster 1981) at Kolkata. The reported PGA for thick alluvium deposit in Kolkata is $0.08 \mathrm{~g}$ (Giardini et al. 1999). Martin and Szeliga (2010) estimate shaking intensity VII (MSK-64/EMS-98) in Kolkata with recurrence interval of 30 years, an interval of time comparable to the design

Table 1. Geotechnical properties of the various soil layers in profiles $B B^{\prime}, C C^{\prime}$ and $D D^{\prime}$.

\begin{tabular}{|c|c|c|c|c|c|}
\hline Formation & $\rho\left(\mathrm{g} / \mathrm{cm}^{3}\right)$ & $V_{p}(\mathrm{~m} / \mathrm{s})$ & $V_{s}(\mathrm{~m} / \mathrm{s})$ & $Q_{p}$ & $Q_{s}$ \\
\hline Top soil & 1.5 & 240 & 140 & 40 & 18 \\
\hline Dark grey silty clay & 1.8 & 260 & 150 & 45 & 20 \\
\hline River channel deposit & 1.9 & 460 & 265 & 50 & 23 \\
\hline Bluish grey silty clay with kankar & 1.85 & 325 & 185 & 60 & 27 \\
\hline Yellowish grey silt with clay binders & 1.9 & 415 & 240 & 60 & 27 \\
\hline Mottled brown/grey silty clay & 1.9 & 460 & 265 & 60 & 27 \\
\hline Light grey clay & 1.9 & 485 & 280 & 60 & 27 \\
\hline Dense greyish brown silty sand & 1.9 & 615 & 355 & 64 & 29 \\
\hline
\end{tabular}
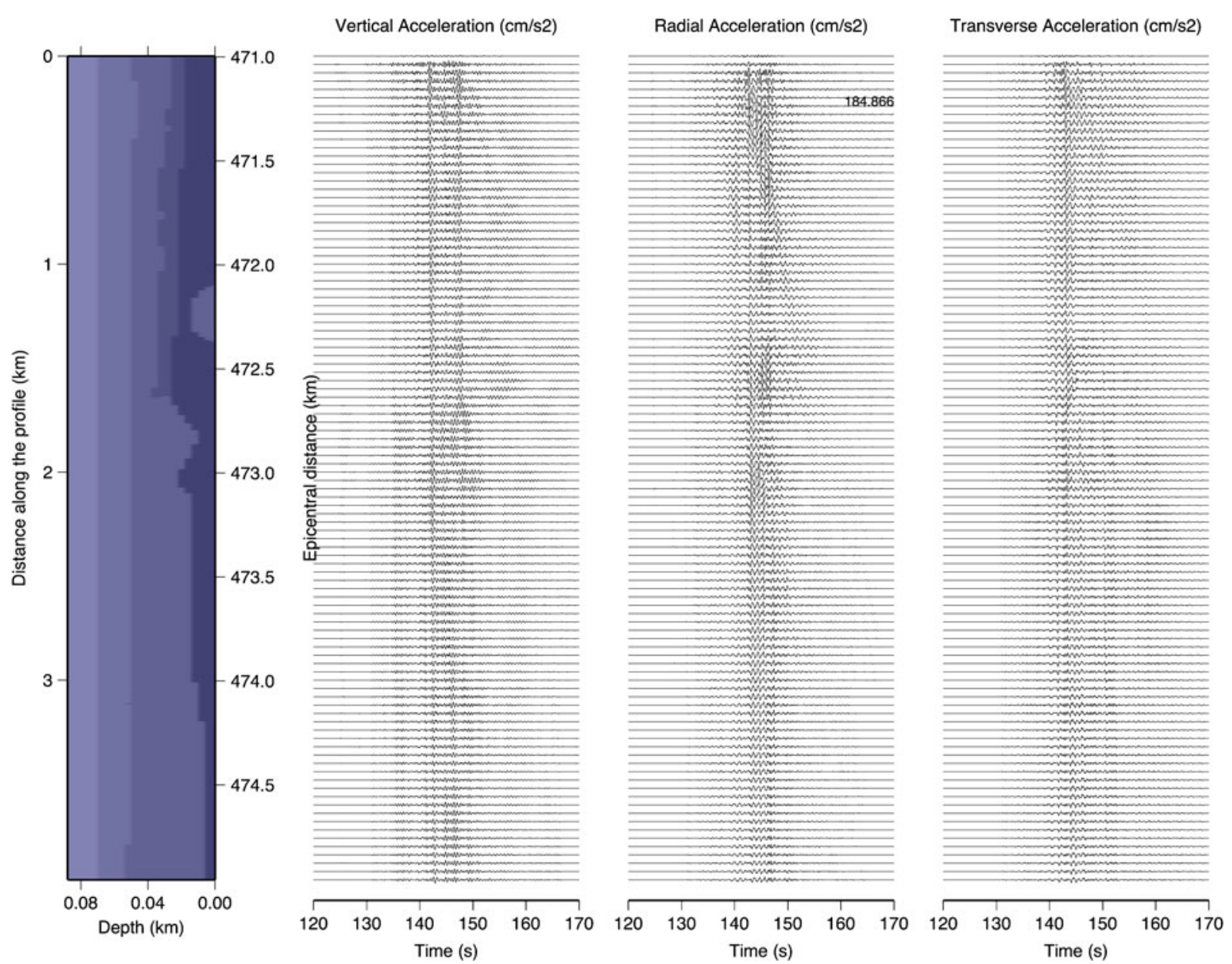

Figure 4. The accelerograms along the geological cross-section $\mathrm{B}^{\prime} \mathrm{B}$ for the three components of ground motion, when the source $\left(M_{w}=8.1\right)$ is at $471 \mathrm{~km}$. The maximum amplitude $\mathrm{A}_{\mathrm{MAX}}$ is indicated in $\mathrm{cm} / \mathrm{s}^{2}$. 
life of most structures. A list of significant earthquakes in the West Bengal state has been compiled by Amateur Seismic Centre (ASC) (available at http://asc-india.org/seismi/seis-westbengal.htm; Gobindraju and Bhattacharya 2012).

\section{Methodology}

In order to estimate the seismic ground motion at a particular site (Kolkata in this study), we calculate synthetic seismograms with the hybrid method developed by Fäh et al. (1994) and Panza et al. (2001), which account simultaneously for the contribution of three factors: (1) seismic source: i.e., how the earthquake source controls the radiation of seismic energy from the fault, (2) travel path: i.e., the effect of the earth through which waves propagate from source to site and (3) local soil condition: i.e., the influence of near surface lateral heterogeneities, and topography, at the site of interest. This hybrid method is a deterministic approach based on the theoretical and computational modelling of wave propagation in laterally heterogeneous media. The hybrid method couples the modal summation (MS) technique (Panza 1985; Florsch et al. 1991; Panza et al. 2001) with the finite difference (FD) method (Alterman and Karal 1968; Boore 1972; Kelly et al. 1976; Virieux 1984, 1986; Levander 1988) and optimizes the use of the advantages of both methods. Wave propagation is treated by means of the modal summation technique from the source to the vicinity of the local, heterogeneous structure that we want to model in detail. A laterally homogeneous anelastic structural model is adopted, which represents the average crustal properties of the region. The generated wavefield is then introduced in the mesh that defines the heterogeneous area, and it is propagated according with the finite difference scheme. Source, path and site effects are all taken into
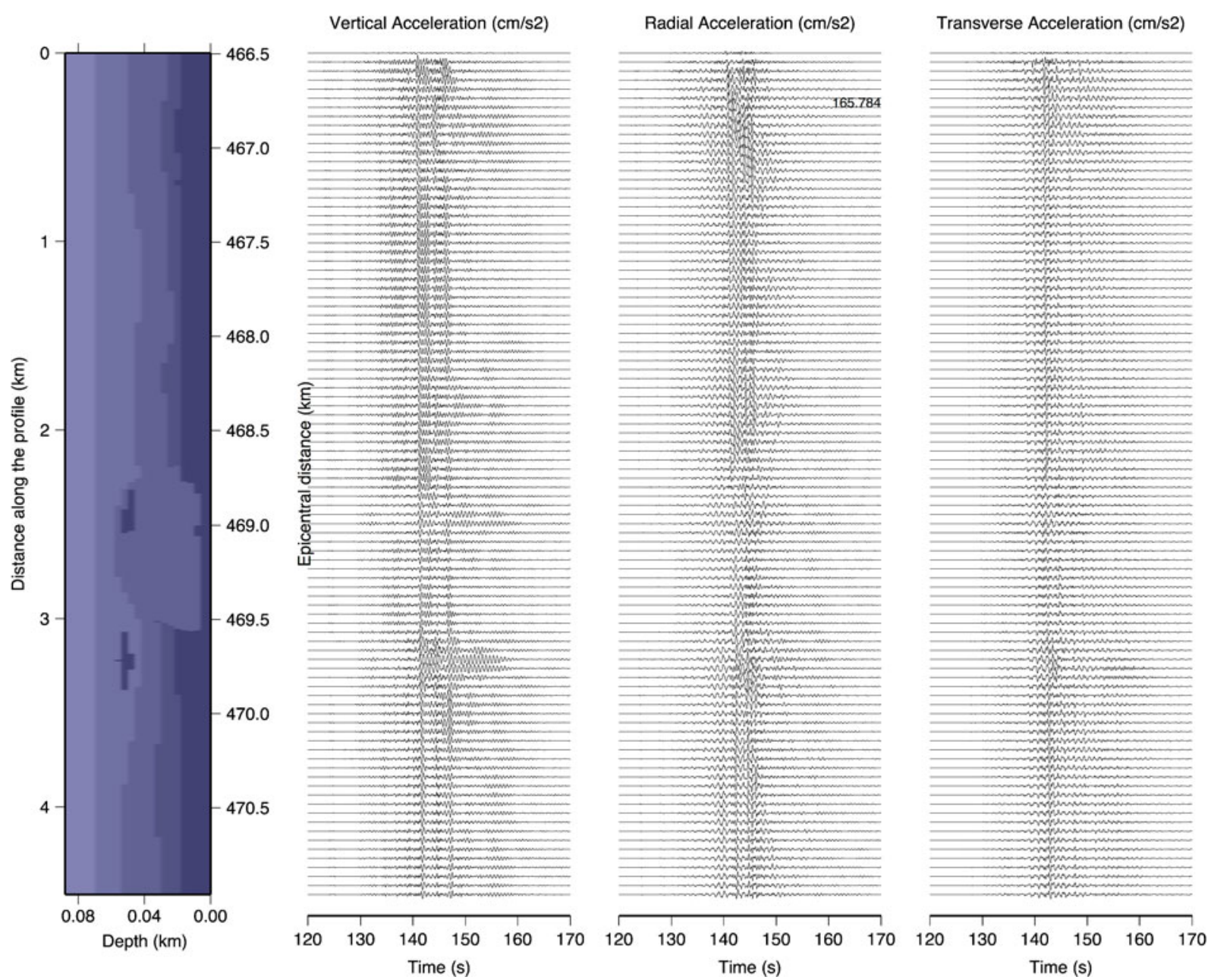

Figure 5. The accelerograms along the geological cross-section $\mathrm{C}^{\prime} \mathrm{C}$ for the three components of ground motion when the source $\left(M_{w}=8.1\right)$ is at $466.5 \mathrm{~km}$. The maximum amplitude $\mathrm{A}_{\mathrm{MAX}}$ is indicated in $\mathrm{cm} / \mathrm{s}^{2}$. 
account, and it is therefore possible a detailed study of the wavefield that propagates even at large distances from the epicenter. The procedure is described in some detail by Panza et al. (2001, 2002), and it has been employed in several studies worldwide (e.g., Fäh et al. 1994; Ding et al. 2004; Parvez et al. 2003, 2006; Zuccolo et al. 2008; Mohanty et al. 2009; Vaccari et al. 2011). The input parameters to be specified are the seismic source parameters of an earthquake scenario and the structural models through which the seismic waves propagate from the source to the site of interest.

\section{Structural models}

The regional model (1-D geological bedrock structure), as shown in figure 3, represents the average properties of the various sub-surface lithologies for the study area and has been published by Parvez et al. (2003), who compiled the available geological and geophysical information for the uppermost $100 \mathrm{~km}$.

The local heterogeneous model (2-D geological cross-section) is prepared from different sources (Ghosh and Gupta 1972; Som 1999; C.E. Testing Company Pvt. Ltd. 2002; Sengupta 2000; Pal 2006) along the Kolkata metro track that runs from Tollygunj to Shyam Bazar station in the N-S direction (figure 2). The entire cross-section $\mathrm{BD}^{\prime}$ is about $13 \mathrm{~km}$ long and the soil profile is available up to a depth of about $60 \mathrm{~m}$. This cross-section has been divided into three part as $\mathrm{BB}^{\prime}=4 \mathrm{~km}, \mathrm{CC}^{\prime}=$ $4.5 \mathrm{~km}$ and $\mathrm{DD}^{\prime}=4.5 \mathrm{~km}$ (figure 2). The details of the geotechnical properties of different soil types are given in table 1. Further geotechnical properties like SPT-N values for different soil deposits in the study region can be found in Gobindraju and Bhattacharya (2012). The effect of the shallow
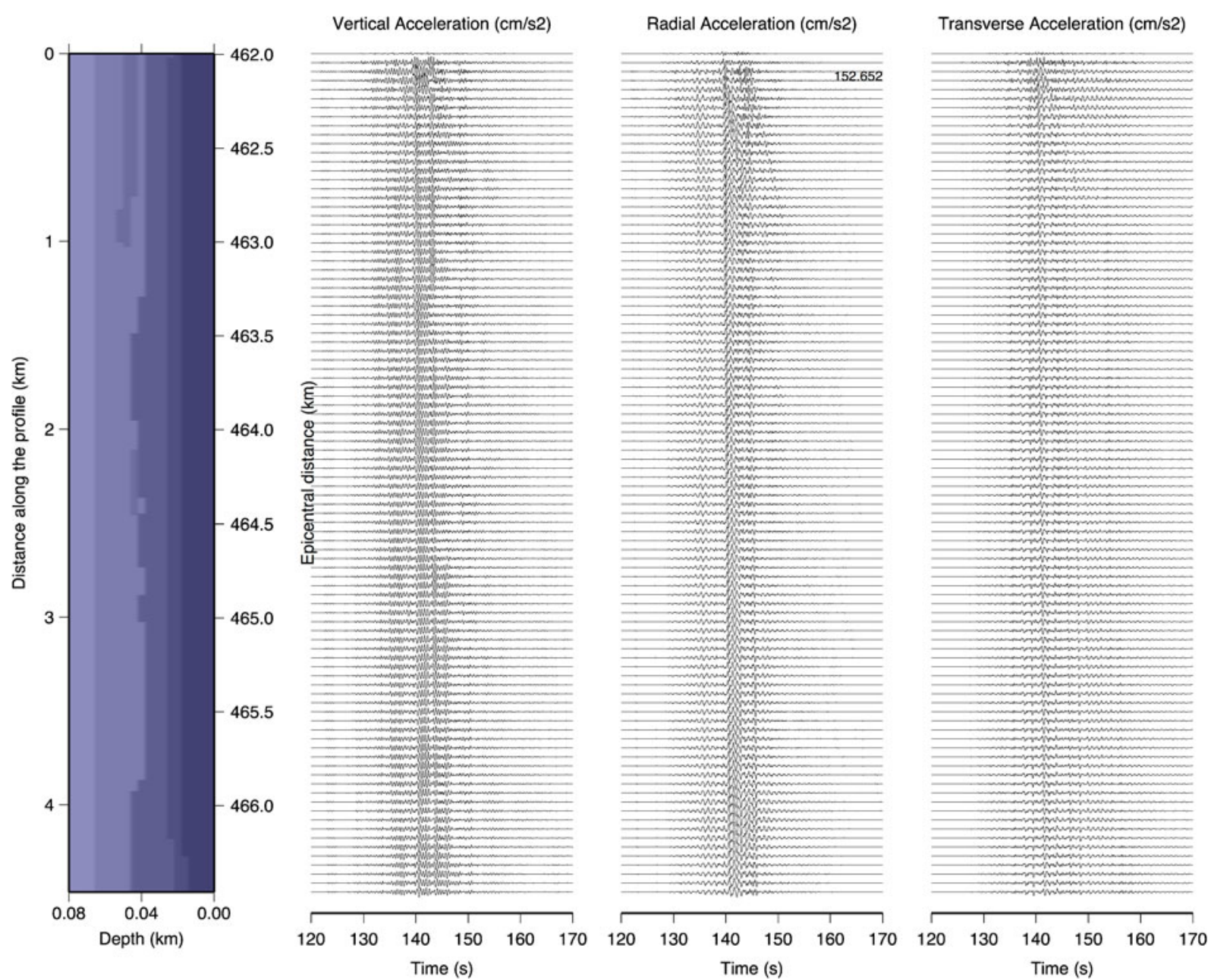

Figure 6. The accelerograms along the geological cross-section $\mathrm{D}^{\prime} \mathrm{D}$ for the three components of ground motion when the source $\left(M_{w}=8.1\right)$ is at $462 \mathrm{~km}$. The maximum amplitude $\mathrm{A}_{\text {MAX }}$ is indicated in $\mathrm{cm} / \mathrm{s}^{2}$. 
sedimentary basin can be assessed by the computation of the spectral ratios between the signals obtained for the 2-D model and the corresponding signals obtained for the bedrock (1-D) model. The sharp jump in S-wave velocity between the shallow sediments of the 2-D model and the underlying 1-D bedrock structure mimics the model given by Mitra et al. (2008).

\section{Earthquake source}

In the present study, the Shillong earthquake of 12 June 1897 is considered with epicenter at about $462 \mathrm{~km}$ of distance from the Shyam Bazar station (figure 2), i.e., from the nearest site of profile $\mathrm{D}^{\prime} \mathrm{B}$. The source parameters of the 1897 Shillong earthquake used in the computation are dip $=57^{\circ}$, strike $=110^{\circ}$ and rake $=76^{\circ}$, focal depth $=9 \mathrm{~km}$,
$M_{w}=8.1$ (Bilham and England 2001). The epicenter of the event is within the EHZ, about $460 \mathrm{~km}$ north of Kolkata (figure 1). A maximum intensity of VIII (MM) (isoseismal 3 in Oldham scale, Oldham 1899) was felt at Kolkata due to this event (GSI 2000).

\section{Computation of the synthetic seismograms}

The geological profiles run from north to south along the metro track in the Kolkata city and the earthquake source (used in computation) is located in the northern side of Kolkata. The accelerograms are generated along the geological cross-sections $\mathrm{B}^{\prime} \mathrm{B}, \mathrm{C}^{\prime} \mathrm{C}$ and $\mathrm{D}^{\prime} \mathrm{D}$ according to the technique described by Panza et al. (2001). The signals were computed analytically (modal summation) along
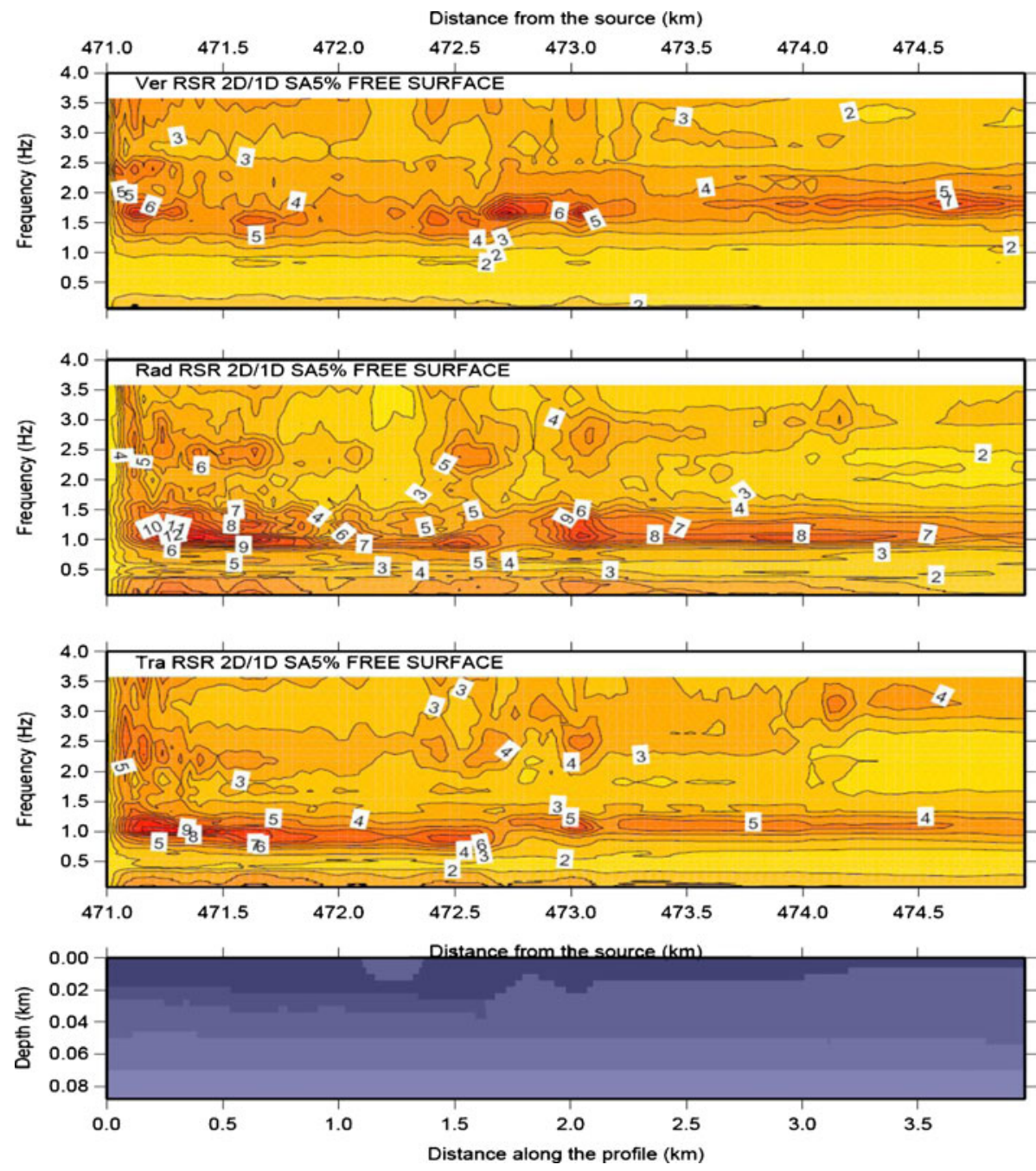

Figure 7. The response spectra ratio (RSR with $5 \%$ damping) versus frequency and epicentral distance along the geological cross-section $\mathrm{B}^{\prime} \mathrm{B}$. 
the path from the source to the site, for frequencies as high as $10 \mathrm{~Hz}$. To account for the epistemic uncertainty about the propagation path, they were subsequently filtered to $\mathrm{f} \leq 3.5 \mathrm{~Hz}$. These signals are then numerically propagated through the laterally varying local structure by the finite difference method considering a grid step of $0.004 \mathrm{~km}$ that obeys the empirical condition that at least 10 points per minimum wavelength are required to assure stability and enough accuracy in the computations. The waveforms are scaled to the desired magnitude in the frequency domain using the scaling law of Gusev (1983) as reported by Aki (1987).

The resulting signals are used for the seismic microzoning via the 'response spectra ratio' (RSR), i.e., the spectral amplification defined by $\mathrm{RSR}=\mathrm{Sa}(2 \mathrm{D}) / \mathrm{Sa}(1 \mathrm{D})$, where $\mathrm{Sa}(2 \mathrm{D})$ is the response spectrum (at 5\% of damping) for the signals calculated in the laterally varying structure, and $\mathrm{Sa}(1 \mathrm{D})$ is the one calculated for signals at the top of the counterpart bedrock reference model.

\section{Results}

The synthetic signals (accelerograms) for the profiles $\mathrm{B}^{\prime} \mathrm{B}, \mathrm{C}^{\prime} \mathrm{C}$ and $\mathrm{D}^{\prime} \mathrm{D}$ are shown in figures 4,5 and 6 , respectively. The peak ground acceleration (PGA) estimated in the study ranges from 0.11 to $0.54 \mathrm{~g}$.

\section{$8.1 B^{\prime} B$ profile}

The maximum acceleration $\left(\mathrm{A}_{\mathrm{MAX}}\right)$ of $0.19 \mathrm{~g}$ is observed in the radial component at the epicentral distance of $471 \mathrm{~km}$, while for the transverse and the
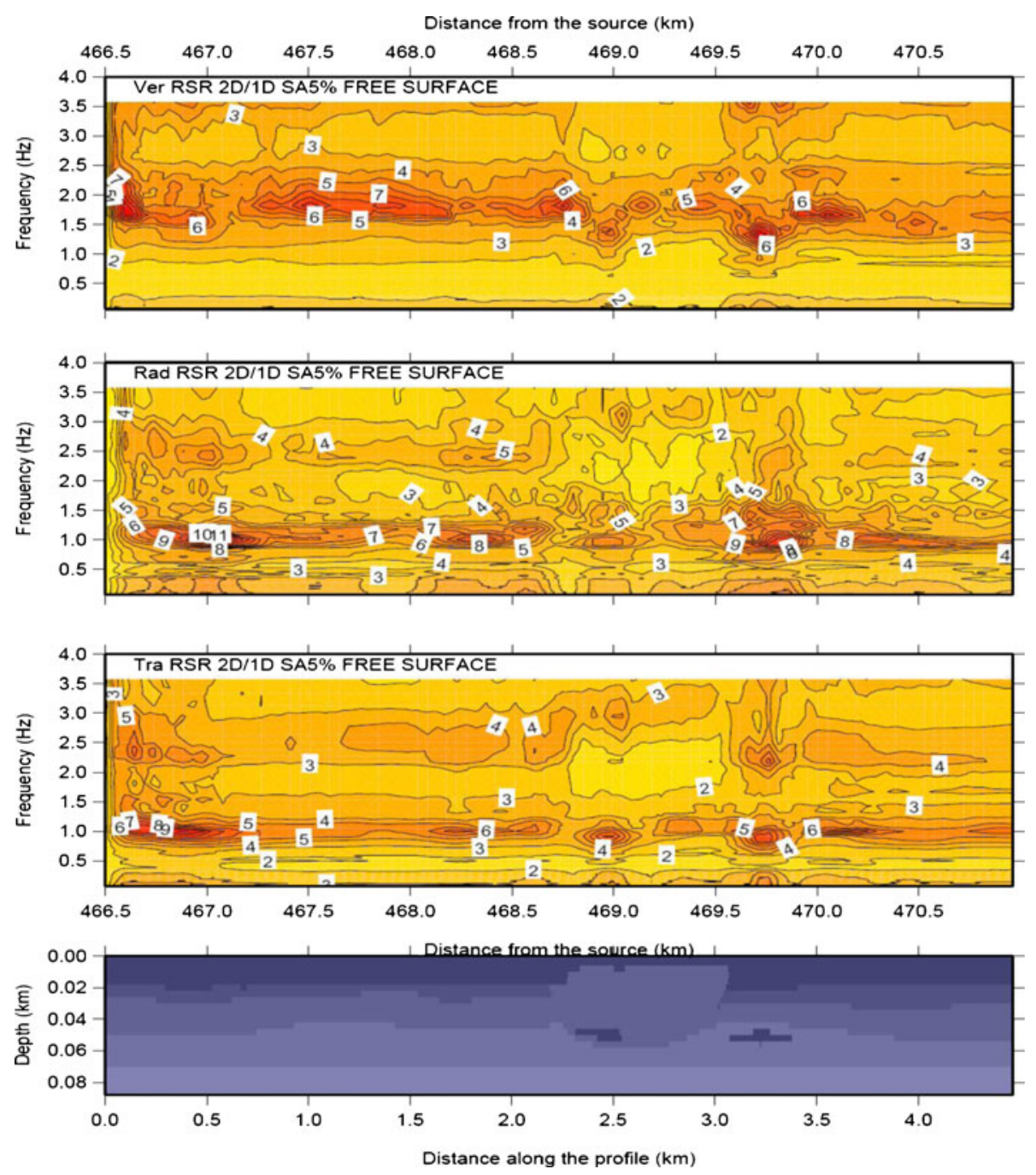

Figure 8. The response spectra ratio (RSR with $5 \%$ damping) versus frequency and epicentral distance along the geological cross-section $\mathrm{C}^{\prime} \mathrm{C}$. 
vertical components, it is 0.14 and $0.13 \mathrm{~g}$, respectively (figure 4). The site amplification is obtained by the distribution of RSR (response spectral ratio with $5 \%$ ) versus frequency and epicentral distance along the profile (figure 7). The maximum amplification is observed in the radial component and equals 12 in the frequency range from 1.0 to $1.5 \mathrm{~Hz}$. The observed amplification for the vertical component is 9 at the frequency of $1.0 \mathrm{~Hz}$, while in the transverse component the amplification is 7 in the frequency range from 1.0 to $2.0 \mathrm{~Hz}$.

\section{$8.2 C^{\prime} C$ profile}

The largest acceleration $\left(\mathrm{A}_{\mathrm{MAX}}=0.17 \mathrm{~g}\right)$ is seen in the radial component at $466.7 \mathrm{~km}$ from source, while for transverse and vertical components, it is 0.14 and $0.13 \mathrm{~g}$, respectively (figure 5).
The site amplification along profile $\mathrm{C}^{\prime} \mathrm{C}$ is shown in figure 8. In this case the absolute maximum amplification is 11 for the radial component at the frequency of $1.0 \mathrm{~Hz}$ and epicentral distance of $462.5 \mathrm{~km}$. For the vertical and transverse components the maximum amplifications are 5-7 in the frequency range from 1.5 to $2.5 \mathrm{~Hz}$ and 5-9 at $1.0 \mathrm{~Hz}$, respectively.

\section{$8.3 D^{\prime} D$ profile}

Peak acceleration $\left(\mathrm{A}_{\mathrm{MAX}}=0.16 \mathrm{~g}\right)$ is reached in the radial component rather than in the transverse $\left(\mathrm{A}_{\mathrm{MAX}}=0.12 \mathrm{~g}\right)$ and vertical $\left(\mathrm{A}_{\mathrm{MAX}}=0.15 \mathrm{~g}\right)$ components (figure 6). These peak values are observed at the distance of $462 \mathrm{~km}$ from source.

The RSR versus frequency and epicentral distance plot along the $\mathrm{D}^{\prime} \mathrm{D}$ profile is shown in figure 9. Maximum amplification around 8-10
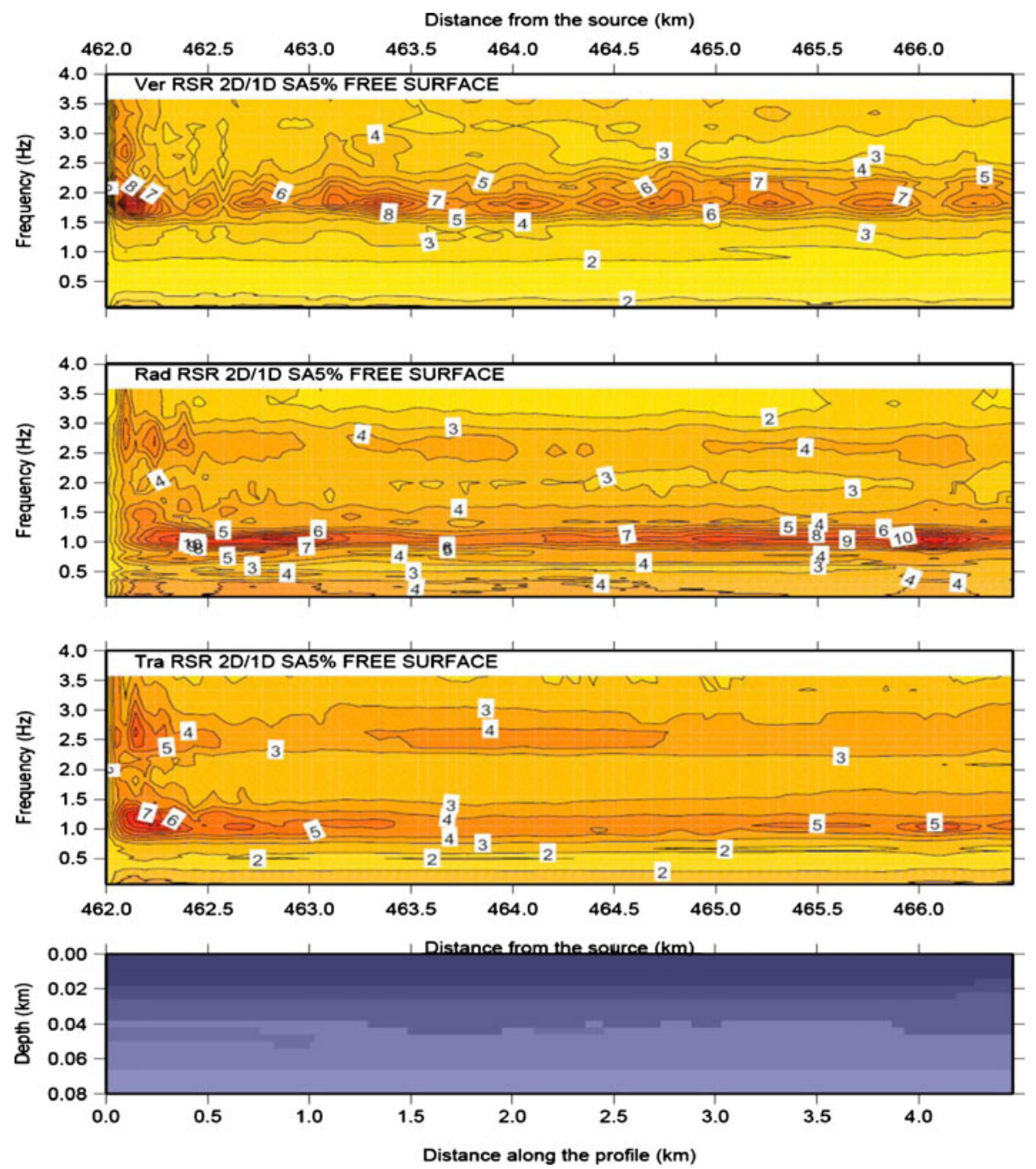

Figure 9. The response spectra ratio (RSR with $5 \%$ damping) versus frequency and epicentral distance along the geological cross-section $\mathrm{D}^{\prime} \mathrm{D}$. 
times is seen at the frequency of $1.0 \mathrm{~Hz}$ in the radial component. For the vertical and transverse components the maximum is 8 at $2.0 \mathrm{~Hz}$ and 7 at $1.3 \mathrm{~Hz}$, respectively.

To find out the effect of epicentral distance, we performed the computation for the radial component (the most amplified component) for distances of 471,400 and $300 \mathrm{~km}$ and the maximum amplification are 12, 13 and 10, respectively, at a common frequency of $1.0 \mathrm{~Hz}$ for section $\mathrm{B}^{\prime} \mathrm{B}$ (figure 10). Therefore, the distance dependence of the amplification, in the considered case, can be as high as $30 \%$.

For $\mathrm{C}^{\prime} \mathrm{C}$ profile, the amplification value of 11 at $1.2 \mathrm{~Hz}, 13$ at $1.2 \mathrm{~Hz}$ and 8 at $1.0 \mathrm{~Hz}$ are observed in radial component for epicentral distance 466.5, 400 and $300 \mathrm{~km}$, respectively, as shown in figure 11. This confirms the dependence of the amplification on epicentral distance.
Figure 12 shows the amplification (RSR) for the radial component for $\mathrm{D}^{\prime} \mathrm{D}$ profile when the source distances are 300,400 and $462 \mathrm{~km}$. For a source distance of $300 \mathrm{~km}$ the amplification is 10 at the frequency of $1.0 \mathrm{~Hz}$ and for an epicentral distance of $400 \mathrm{~km}$ it is 6 at $1.2 \mathrm{~Hz}$, however for $462 \mathrm{~km}$ source distance the amplification is 10 at the frequency of $1.0 \mathrm{~Hz}$.

The variations, with epicentral distance and source properties, of amplification values and peak's frequency are given in table 2 , where the results of Vaccari et al. (2011) are reported as well.

\section{Discussion and conclusion}

The peak ground acceleration (PGA) and response spectral ratio (RSR) in the Kolkata city due to a scenario earthquake in the Shillong plateau varies
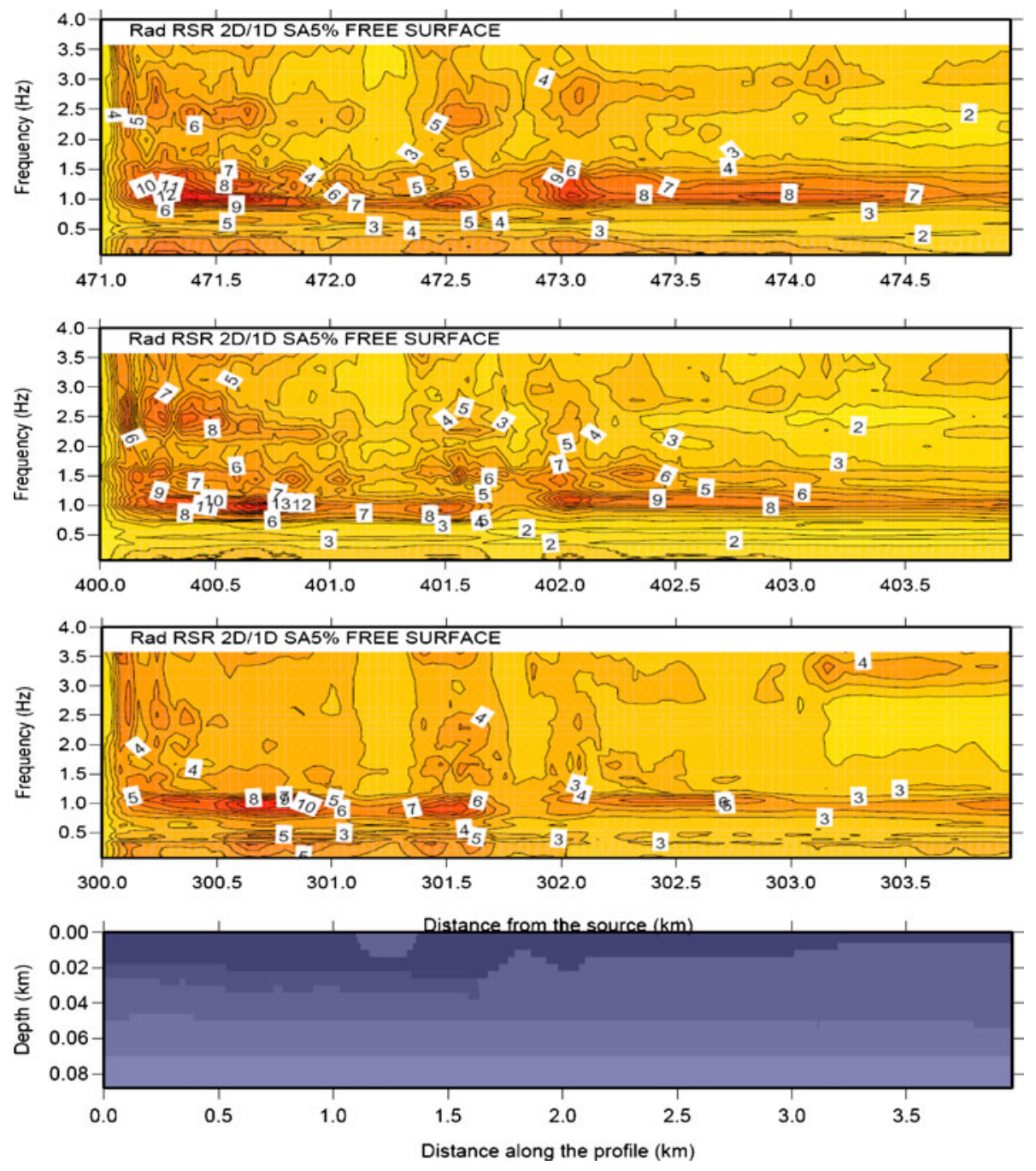

Figure 10. The radial component of response spectra ratio (RSR with $5 \%$ damping) versus frequency and epicentral distance along the geological cross-section $\mathrm{B}^{\prime} \mathrm{B}$ for epicentral distances of 300,400 and $471 \mathrm{~km}$. 

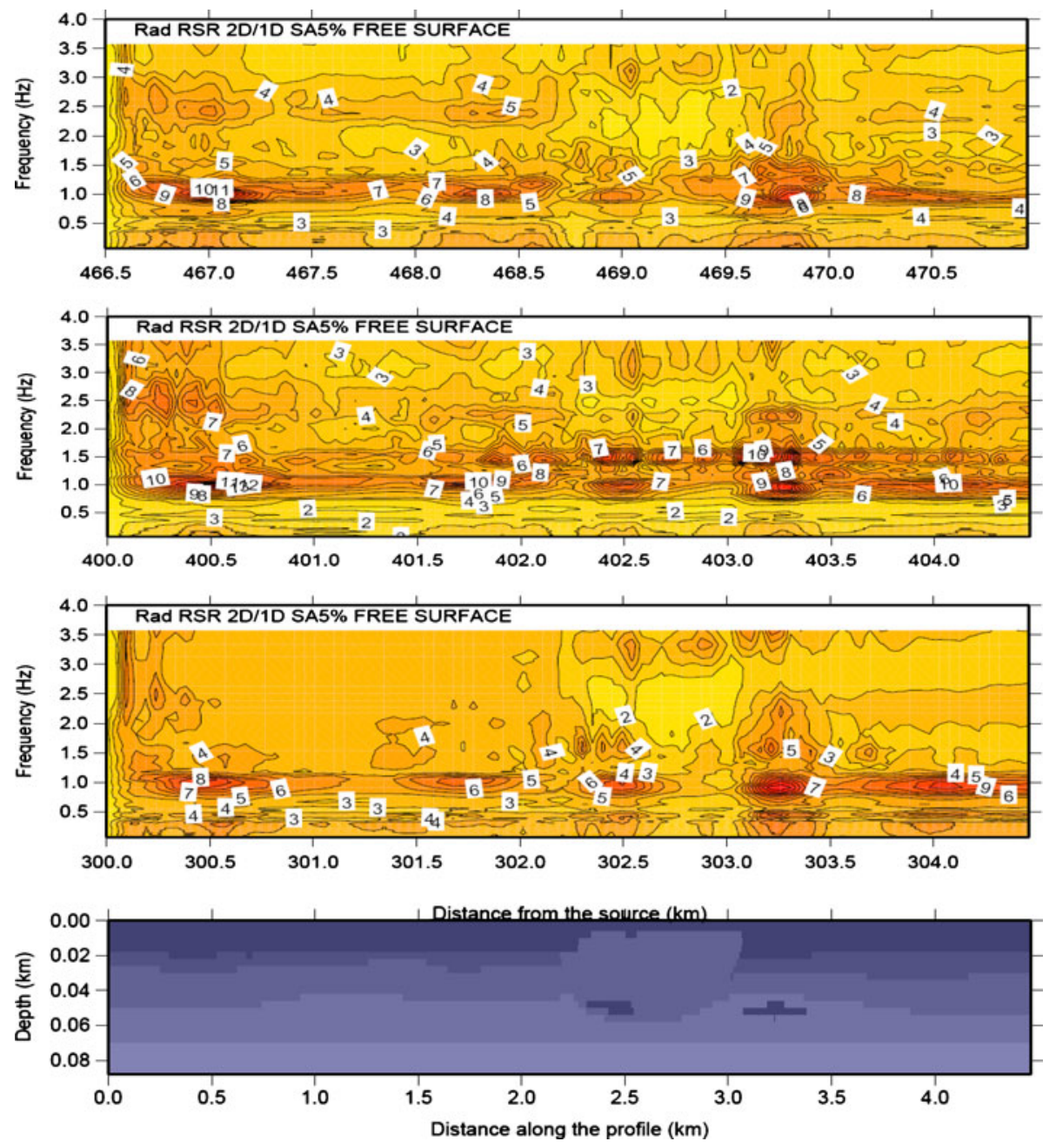

Figure 11. The radial component of response spectra ratio (RSR with $5 \%$ damping) versus frequency and epicentral distance along the geological cross-section $\mathrm{C}^{\prime} \mathrm{C}$ for epicentral distances of 300,400 and $466.5 \mathrm{~km}$.

from 0.11 to $0.18 \mathrm{~g}$. This acceleration range corresponds to the intensity IX to X on the MCS intensity scale (Panza et al. 1997) and VIII on the Modified Mercalli (MM) scale (Bolt 2004). The maximum amplification in terms of RSR (with $5 \%$ damping) is observed in the radial components for all profiles and varies from 10 to 12 in the frequency range from 1.0 to $1.5 \mathrm{~Hz}$. These amplifications are observed at sites characterized by shallow, loose, low velocity soil deposits. The area where extreme PGA (or macroseismic intensity) are computed will be, very likely, completely destroyed with great loss of property, at the occurrence of the considered earthquake scenario. The obtained ground motion level in the Kolkata city due to distant earthquake (e.g., 1897 Shillong earthquake, $\sim 460 \mathrm{~km}$ away from Kolkata) is in agreement with the study of Bhattacharya et al. (2011), where significant destructions are reported in the Kanto due to the 2011 Tohoku (Japan) earthquake occurred at an epicentral distance of $\sim 450 \mathrm{~km}$.
To assess the effect of the epicentral distance on ground motion variations in Kolkata, we have computed the seismic ground motion parameters (i.e., PGA and RSR) for different distances (e.g., actual epicentral distance of each profile, and assumed distances of $400 \mathrm{~km}$ and $300 \mathrm{~km}$ ) keeping fixed source mechanism and local properties of sites. Figure 10 shows the amplification pattern for the radial component, along the profile $\mathrm{B}^{\prime} \mathrm{B}$, at 300,400 and $471 \mathrm{~km}$ of epicentral distance. The radial amplification versus source distance for the profiles $\mathrm{C}^{\prime} \mathrm{C}$ and $\mathrm{D}^{\prime} \mathrm{D}$ is plotted in figures 11 and 12 , respectively. The PGA values for epicentral distances of $471 \mathrm{~km}$ and $400 \mathrm{~km}$ vary in the range from 0.11 to $0.19 \mathrm{~g}$, while for the epicentral distance of $300 \mathrm{~km}$ PGA ranges from 0.24 to $0.54 \mathrm{~g}$. The amplification varies slightly for distances 300,400 and $471 \mathrm{~km}$ and the frequency of the peak values varies in a small range (figures 10, 11 sand 12 for profile $\mathrm{B}^{\prime} \mathrm{B}, \mathrm{C}^{\prime} \mathrm{C}$ and $\mathrm{D}^{\prime} \mathrm{D}$, respectively). Therefore, we can say that, for the cases considered, the relative seismic response 

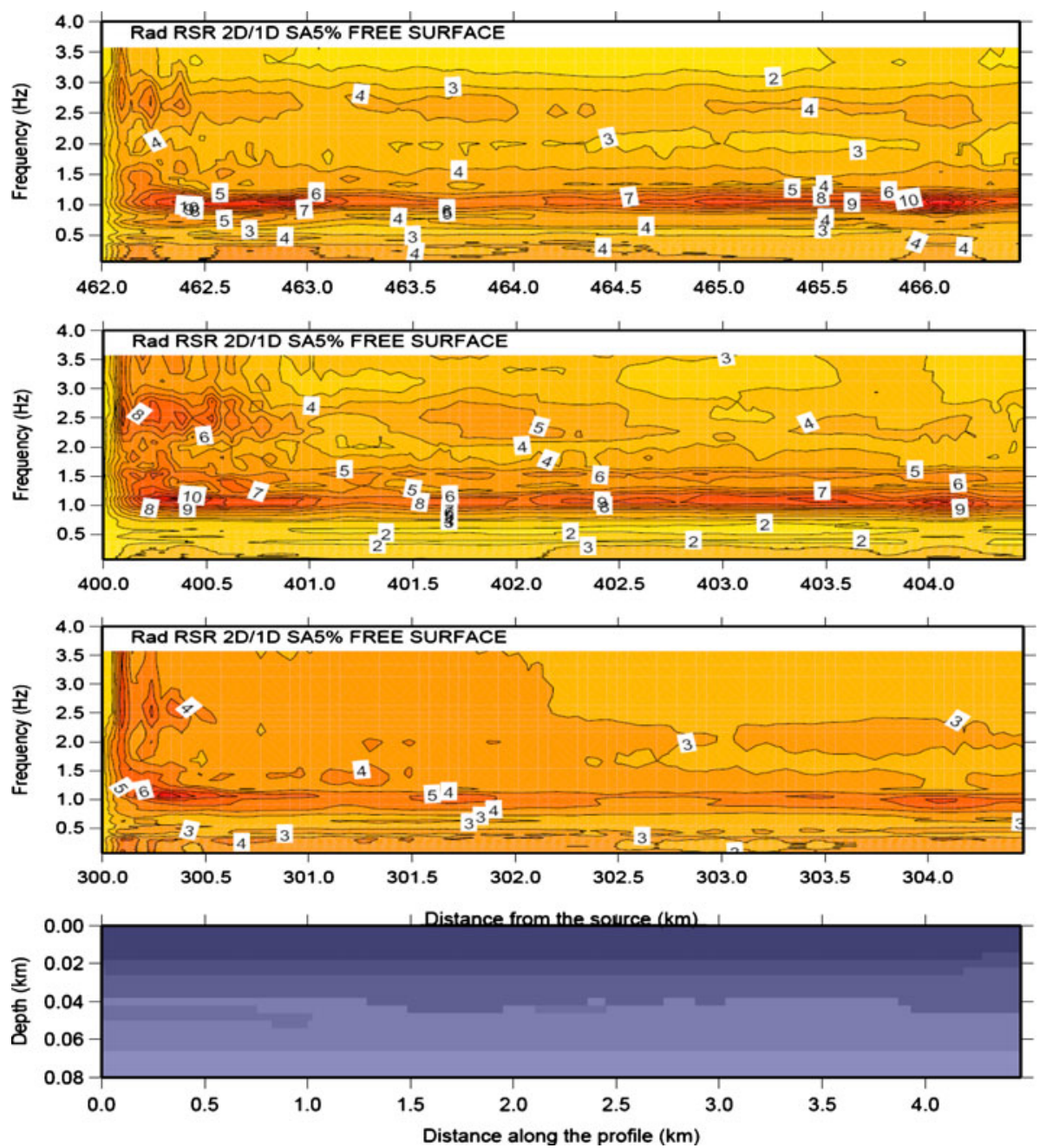

Figure 12. The radial component of response spectra ratio (RSR with $5 \%$ damping) versus frequency and epicentral distance along the geological cross-section $\mathrm{D}^{\prime} \mathrm{D}$ for epicentral distances of 300,400 and $462 \mathrm{~km}$.

(in terms of RSR) does not vary significantly with changes in epicentral distance.

In addition we compare, for the same sites, our results (i.e., seismic response in Kolkata due to an $M_{w}=8.1$ source at an epicentral distance of about $460 \mathrm{~km}$ in the Shillong plateau) with the results of Vaccari et al. (2011), who considered as scenario the Calcutta earthquake of 15 April 1964 $\left(M_{w}=6.5\right)$ located at about $100 \mathrm{~km}$ from Kolkata. The maximum acceleration $\left(\mathrm{A}_{\mathrm{MAX}}\right)$ for the near source $\left(M_{w} 6.5\right)$ is $0.17 \mathrm{~g}$ and for the far source $\left(M_{w}\right.$ 8.1 ) it is $0.18 \mathrm{~g}$. The comparative analysis of amplification, performed up to the frequency of $3.5 \mathrm{~Hz}$, shows that the frequency ranges corresponding to peak amplifications are quite similar for near and distant earthquake scenarios, although there is a slight variation in the amplification values. This may be because, for the near source the scenario magnitude considered is $M_{w}=6.5$ and for the far source the magnitude is $M_{w}=8.1$, and therefore we can say that there is a compensation of the effect of source magnitude with that of distance on site response in Kolkata city.

Although the peak ground acceleration (PGA) varies with varying source parameters (focal mechanism) and epicentral distance, we can conclude that the site response in terms of RSR (i.e., the ratio of response spectra (2-D) to response spectra (1-D), plotted as a function of frequency) at similar site conditions shows similarities in amplification and corresponding frequencies. The major finding from this study suggests that the PGA for $300 \mathrm{~km}$ epicentral distance is $0.54 \mathrm{~g}$ and for $400 \mathrm{~km}$ and $471 \mathrm{~km}$ it is in the range from 0.18 to $0.19 \mathrm{~g}$. The frequency that corresponds to peak amplifications does not vary although amplification values vary slightly. This implies that the frequency that corresponds to peak values is a weak function of the location and property of the source. The finding of an almost constant response is not a general property, but it is true for the scenario earthquakes considered in the present study. The obtained PGA 
Table 2. Comparison of estimated maximum amplifications for each ground components along three profiles for two different sources. The amplifications for the Shillong earthquake are computed in this study while those for the 1964 event are taken from the work done by Vaccari et al. (2011).

\begin{tabular}{|c|c|c|c|c|c|}
\hline $\begin{array}{l}\text { Profile } \\
\text { name }\end{array}$ & Source parameters used & Component & $\begin{array}{l}\text { Maximum } \\
\text { amplification } \\
\text { factor }\end{array}$ & Frequency $(\mathrm{Hz})$ & $\begin{array}{c}\text { Distance } \\
\text { from the source } \\
(\mathrm{km})\end{array}$ \\
\hline \multirow[t]{6}{*}{$\mathrm{BB}^{\prime}$} & \multirow{3}{*}{$\begin{array}{l}M_{w}=8.1, \operatorname{dip}=57^{\circ} \\
\text { strike }=110^{\circ}, \text { rake }=76^{\circ} \\
\text { and focal depth }=9 \mathrm{~km} \\
(1897, \text { Shillong earthquake })\end{array}$} & Vertical & 7 & $1.5-2.0$ & $471.1,473,474.5$ \\
\hline & & Radial & 12 & $1.0-1.5$ & 471.2 \\
\hline & & Transverse & 9 & 1.0 & 471.3 \\
\hline & \multirow{3}{*}{$\begin{array}{l}M_{w}=6.5, \operatorname{dip}=32^{\circ}, \\
\text { strike }=232^{\circ}, \text { rake }=56^{\circ} \\
\text { and focal depth }=36 \mathrm{~km} \\
(1964, \text { Calcutta earthquake) }\end{array}$} & Vertical & 6 & $1.5-2.3$ & $96.6,98.2-98.7,99.5$ \\
\hline & & Radial & 8 & 1.0 & $97.0,99.0$ \\
\hline & & Transverse & 5 & $1.0-1.5$ & 96.6 \\
\hline \multirow[t]{6}{*}{$\mathrm{CC}^{\prime}$} & \multirow{3}{*}{$\begin{array}{l}M_{w}=8.1, \operatorname{dip}=57^{\circ} \\
\text { strike }=110^{\circ}, \text { rake }=76^{\circ} \\
\text { and focal depth }=9 \mathrm{~km} \\
(1897, \text { Shillong earthquake })\end{array}$} & Vertical & 7 & $1.5-2.3$ & $466.5,467.3$ \\
\hline & & Radial & 11 & $1.0-1.5$ & 467 \\
\hline & & Transverse & 9 & 1.0 & 466.2 \\
\hline & \multirow{3}{*}{$\begin{array}{l}M_{w}=6.5, \operatorname{dip}=32^{\circ}, \\
\text { strike }=232^{\circ}, \text { rake }=56^{\circ} \\
\text { and focal depth }=36 \mathrm{~km} \\
(1964, \text { Calcutta earthquake) }\end{array}$} & Vertical & 8 & $1.5-2.5$ & $102-102.5$ \\
\hline & & Radial & 10 & 1.0 & 101 \\
\hline & & Transverse & 6 & 1.0 & 100.3 \\
\hline \multirow[t]{6}{*}{$\mathrm{DD}^{\prime}$} & \multirow{3}{*}{$\begin{array}{l}M_{w}=8.1, \operatorname{dip}=57^{\circ} \\
\text { strike }=110^{\circ}, \text { rake }=76^{\circ} \\
\text { and focal depth }=9 \mathrm{~km} \\
(1897, \text { Shillong earthquake })\end{array}$} & Vertical & 8 & $1.5-2.0$ & $462.2,663.4$ \\
\hline & & Radial & 10 & $1.0-1.3$ & $462.4,466$ \\
\hline & & Transverse & 7 & $1.0-1.5$ & 462.3 \\
\hline & \multirow{3}{*}{$\begin{array}{l}M_{w}=6.5, \operatorname{dip}=32^{\circ}, \\
\text { strike }=232^{\circ}, \text { rake }=56^{\circ} \\
\text { and focal depth }=36 \mathrm{~km} \\
(1964, \text { Calcutta earthquake) }\end{array}$} & Vertical & 8 & $1.5-2.0$ & 106.4 \\
\hline & & Radial & 10 & 1.0 & $105.5,108.6$ \\
\hline & & Transverse & 7 & 1.0 & 105.4 \\
\hline
\end{tabular}

Table 3. $P G A$ for $B^{\prime} B, C^{\prime} C$ and $D^{\prime} D$ profiles with varying source mechanism with fixed magnitude and epicentral distance.

\begin{tabular}{lcc}
\hline & $\begin{array}{r}\text { strike }=110^{\circ}, \text { dip }=57^{\circ} \\
\text { and rake }=76^{\circ} ; \\
\text { focal depth }=9 \mathrm{~km}\end{array}$ & $\begin{array}{c}\text { strike }=232^{\circ}, \text { dip }=32^{\circ} \\
\text { and rake }=56^{\circ} ; \\
\text { focal depth }=36 \mathrm{~km}\end{array}$ \\
\hline $\mathrm{B}^{\prime} \mathrm{B}$ & $0.135 \mathrm{~g}$ & $0.037 \mathrm{~g}$ \\
Transverse & $0.188 \mathrm{~g}$ & $0.131 \mathrm{~g}$ \\
Radial & $0.130 \mathrm{~g}$ & $0.089 \mathrm{~g}$ \\
Vertical & & $0.039 \mathrm{~g}$ \\
$\mathrm{C}^{\prime} \mathrm{C}$ & $0.137 \mathrm{~g}$ & $0.159 \mathrm{~g}$ \\
Transverse & $0.169 \mathrm{~g}$ & $0.080 \mathrm{~g}$ \\
Radial & $0.130 \mathrm{~g}$ & $0.039 \mathrm{~g}$ \\
Vertical & & $0.136 \mathrm{~g}$ \\
$\mathrm{D}^{\prime} \mathrm{D}$ & $0.118 \mathrm{~g}$ & $0.076 \mathrm{~g}$ \\
Transverse & $0.155 \mathrm{~g}$ & $\mathrm{~g}$ \\
Radial & $0.148 \mathrm{~g}$ & \\
Vertical & &
\end{tabular}

Magnitude $\left(M_{w}=8.1\right)$ and distance are the same for each profile (i.e., $471 \mathrm{~km}$ for $\mathrm{B}^{\prime} \mathrm{B}, 466.5 \mathrm{~km}$ for $\mathrm{C}^{\prime} \mathrm{C}$ and $462 \mathrm{~km}$ for $\mathrm{D}^{\prime} \mathrm{D}$ profile).

does not follow a clear pattern in terms of their distribution in the magnitude-distance space and this result is consistent with the observation reported by Strasser and Bommer (2009a). Furthermore, the comparison of PGA values, for the same epicentral distance and magnitude, but with 
different focal mechanism, shows a variation in the PGA values (table 3 ). Therefore, the ground response may also depend on some other property (e.g., size and orientation of the fault, duration, topographic effect, etc.,) rather than location and property of the source.

Therefore, for Kolkata, as it has been clearly shown in our analysis, the reliable assessment of seismic hazard requires that the ground response should be evaluated for different scenario earthquakes with varying epicentral distances and source parameters.

The ground motion parameters we have computed are well in agreement with the observed intensities in Kolkata reported due to near and far earthquakes. Therefore, in the absence of real strong motion data recorded in Kolkata, the synthetic time series can be used to estimate the expected ground motion, thus leading towards predisaster microzonation without having to wait for an earthquake to occur. The estimated results can be fruitfully used and analyzed by civil engineers for design, urban planning and retrofitting of the existing build environment and therefore can be used as guidelines for the effective mitigation of seismic hazard in Kolkata.

\section{References}

Aki K 1987 Strong motion seismology; In: Strong Ground Motion Seismology (eds) Erdik M and Toksoz M, Reidel, Dordrecht, NATO ASI Series C, Mathematical and Physical Science 204 3-39.

Alterman Z S and Karal F C 1968 Propagation of elastic waves in layered media by finite difference methods; Bull. Seismol. Soc. Am. 58 367-398.

Bhattacharya S, Hyodo M, Goda K, Tazoh T and Taylor C A 2011 Liquefaction of soil in the Tokyo Bay area from the 2011 Tohoku (Japan) earthquake; Soil Dynam. Earthq. Eng. 31 1618-1628.

Bilham R and England P 2001 Plateau "pop-up" in the great 1897 Assam earthquake; Nature 410 806-809.

Bolt B A 2004 Earthquakes; W H Freeman and Company, New York, 349p.

Bommer J J, Benito M B, Ciudad-Real M, Lemoine A, Lopez-Menjivar M A, Madariaga R, Mankelow J, Mendez de Hasbun P, Murphy W, Nieto-Lovo M, Rodriguez-Pineda C E and Rosa H 2002 The El Salvador earthquakes of January and February 2001: Context, characteristics and implications for seismic risk; Soil Dynam. Earthq. Eng. 22 389-418.

Boore D M 1972 Finite difference methods for seismic waves propagation in heterogeneous materials; In: Methods in Computational Physics (ed.) Bolt B A (New York: Academic Press) 11 1-37.

Brune J N 1970 Tectonic stress and the spectra of seismic shear waves from earthquakes; J. Geophys. Res. $\mathbf{7 5}$ 4997-5009.

C. E. Testing Company Pvt. Ltd. 2002 Report on Soil Investigation Work for the Proposed Multi-storied Building at 375, Prince Anwar Shah Road, Kolkata, November 2002 (unpublished).
Chandra 1977 Earthquake of peninsular India - A seismotectonic study; Bull. Seismol. Soc. Am. 67 1387-1413.

Clough R and Pension J 1993 Dynamics of structures; (New York: McGraw Hill).

Curray J R and Moore D G 1971 The growth of the Bengal deep-sea fan and denudation in the Himalayas; Geol. Soc. Am. Bull. 82 563-572.

Decanini L, Gavarini C and Mollaioli F 1995 Proposta di definizione delle relazioni tra intensita' macrosismica e parametri del moto del suolo; Atti $7^{0}$ Convegno L'ingegnaria sismica in Italia 1 63-72.

Decanini L and Mollaioli F 1998 Formulation of Elastic Earthquake Input Energy Spectra; Earthq. Eng. Struct. Dynam. 27 1503-1522.

Ding Z, Chen Y T and Panza G F 2004 Estimation of site effects in Beijing city; Pure Appl. Geophys. 161 11071123.

Dunn J A, Auden J B and Ghosh A M N 1939 The Bihar Nepal earthquake of 1934; Geol. Surv. India Memoir $\mathbf{7 3}$ (reprinted 1981) 27-48.

Fäh D and Panza G F 1994 Realistic modeling of observed seismic motion in complex sedimentary basins; Ann. Geofis. 37 1771-1797.

Fäh D, Iodice C, Suhadolc P and Panza G F 1993 A new method for the realistic estimation of seismic ground motion in megacities, the case of Rome; Earthquake Spectra 9 643-668.

Fäh D, Suhadolc P, Mueller St and Panza G F 1994 A hybrid method for the estimation of ground motion in sedimentary basins; Quantitative modelling for Mexico city; Bull. Seismol. Soc. Am. 84 383-399.

Field E H and the SCEC Phase III Working Group 2000 Accounting for site effects in probabilistic seismic hazard analyses of Southern California: Overview of the SCEC Phase III Report; Bull. Seismol. Soc. Am. 90 S1-S31.

Florsch N, Fäh D, Suhadolc P and Panza G F 1991 Complete synthetic seismograms for high-frequency multimode SHwave; Pure Appl. Geophys. 136 529-560.

Ganguly S 1997 Petroleum geology and exploration history of the Bengal basin in India and Bangladesh; Ind. J. Geol. 69(1) $1-25$.

Ghosh P K and Gupta S 1972 Subsoil character of Calcutta region; In: Proc. Third Symp. on Application of Soil Mech. and Found. Engg. in Eastern India, Calcutta, Dec. 1972, pp. 25-45.

Giardini D, Grunthal G, Shedlock K M and Zhang P 1999 GSHAP Global Seismic Hazard Map; Ann. Geofis. 42(6) 1225-1230.

Gobindraju L and Bhattacharya S 2012 Site-specific earthquake response study for hazard assessment in Kolkata city, India; Nat. Hazards 61(3) 943-965, doi: 10.1007/s11069-011-9940-3.

GSI - Geological Survey of India 2000 Seismotectonic Atlas of India and its environs.

Gusev A A 1983 Descriptive statistical model of earthquake source radiation and its application to an estimation of short period strong motion; Geophys. J. Roy. Astron. Soc. 74 787-808.

Hanks T C and Johnson D A 1976 Geophysical assessment of peak acceleration; Bull. Seismol. Soc. Am. 66 959-968.

IS: 1893 (Part 1) 2002 Indian standard criteria for earthquake resistant design of structures, Part 1 - General provisions and buildings, Bureau of Indian Standards, New Delhi.

Jhingran A G, Karunakaran C and Krishnamurthy J G 1969 The Calcutta earthquakes of 15th April and 9th June, 1964; Records Geol. Surv. India 97(2) 1-29. 
Kelly K R, Ward R W, Treitel S and Alford R M 1976 Synthetic seismograms: A finite difference approach; Geophysics 41 2-27.

Khan A A and Agarwal B N P 1993 The crustal structure of western Bangladesh from gravity data; Tectonophys. 219 341-353.

Khan M R and Muminullah M 1980 Stratigraphy of Bangladesh; In: Proceedings of petroleum and mineral resources of Bangladesh, Ministry of Petroleum and Mineral Resources, Government of Bangladesh, pp. 35-40.

Khandoker R A 1989 Development of major tectonic elements of the Bengal basin: A plate tectonic appraisal; Bangladesh J. Sci. Res. 7 221-232.

Levander A R 1988 Fourth-order finite-difference P-SV seismograms; Geophysics 53 1425-1436.

Martin S and Szeliga W 2010 A catalog of felt intensity data for 570 earthquakes in India from 1636 to 2009; Bull. Seismol. Soc. Am. 100 562-569.

Middlemiss C S 1908 Two Calcutta earthquakes of 1906; Records Geol. Surv. India 36(3) 214-232.

Mishra P S 2004 Seismic hazard and risk microzonation of Jabalpur; Paper presented at the Workshop on Seismic Hazard and Risk Microzonation of Jabalpur, National Geophysical Research Institute, Hyderabad, India.

Mitra S, Bhattacharya S N and Nath S K 2008 Crustal structure of the western Bengal basin from joint analysis of teleseismic receiver functions and Rayleigh-wave dispersion; Bull. Seismol. Soc. Am. 98 2715-2723.

Mohanty W K and Walling M Y 2008a Seismic hazard in mega city Kolkata, India; Nat. Hazards 47(1) 39-54.

Mohanty W K and Walling M Y 2008b First order seismic microzonation of Haldia, Bengal basin (India) using a GIS Platform; Pure Appl. Geophys. 165(7) 13251350.

Mohanty W K, Walling M Y, Nath S K and Pal I 2007 First order seismic microzonation of Delhi, India using Geographic Information System (GIS); Nat. Hazards 40(2) 245-260.

Mohanty W K, Walling M Y, Vaccari F, Tripathy T and Panza G F 2009 Modelling of SH- and P-SVwave fields and seismic microzonation based on response spectra ratio for Talchir Basin, India; Eng. Geol. 104 84-97.

Mohraz B 1978 Influences of the magnitude of the earthquake and the duration of strong motion on earthquake response spectra; In: Proceedings of the Central American Conference on Earthquake Engineering, San Salvadore.

Murphy R W 1988 Bangladesh enters the oil era; Oil and Gas Journal 86(9) 76-82.

Murty A S N, Sain K and Prasad B R 2008 Velocity structure of the West Bengal sedimentary basin, India along the Palashi-Kandi profile using a traveltime inversion of wideangle seismic data and gravity modeling - An update; Pure Appl. Geophys. 165 1733-1750.

Nandy D R 2001 Geodynamics of northeastern Indian and the adjoining region (Kolkata: ACB Publications), pp. 1-209.

Nath S K 2004 Seismic hazard mapping and microzonation in the Sikkim Himalaya through GIS integration of site effects and strong ground motion attributes; Nat. Hazards 31(2) 319-342.

Oldham R D 1899 Report on the great earthquake of 12th June, 1897; Geol. Surv. India Memoir 29 1-379.

Oldham T 1883 A catalogue of Indian earthquakes from the earliest time to the end of 1869 AD; Geol. Surv. India Memoir, pp. 163-215.
Pal S 2006 Cyclic Behaviour of Gangetic Soil; M Tech Thesis, IIT Kharagpur (unpublished).

Panza G F 1985 Synthetic seismograms: The Rayleigh waves modal summation; J. Geophys. 58 125-145.

Panza G F, Alvarez L, Aoudia A, Ayadi A, Benhallou H, Benouar D, Bus Z, Chen Yun-Tia, Cioflan C, Ding Zhifeng, El-Sayed A, Garcia J, Garofalo B, Gorshkov A, Gribovszki K, Harbi A, Hatzidimitriou P, Herak M, Kouteva M, Koznetzou I, Lokmer I, Maouche S, Marmureanu G, Matova M, Natale M, Nunziata C, Parvez I, Paskaleva I, Pico R, Radulian M, Romanelli F, Soloviev A, Suhadolc P, Triantafylldis P and Vaccari F 2002 Realistic modeling of seismic input for megacities and large urban areas (the UNESCO/IUGS/IGCP project 414); Episodes 253 160-184.

Panza G F, Cazzaro R and Vaccari F 1997 Correlation between macroseismic intensities and seismic ground motion parameters; Ann. Geofis. XL N5 1371-1382.

Panza G F, Irikura K, Kouteva M, Peresan A, Wang Z and Saragoni R (eds) 2011 Topical Volume on "Advanced seismic hazard assessments"; Pure Appl. Geophys. 168, ISBN 978-3-0348-0039-6 \& ISBN: 978-3-0348-0091-4, 752p.

Panza G F, Romanelli F and Vaccari F 2001 Seismic wave propagation in laterally heterogeneous anelastic media: Theory and application to seismic zonation; In: Advances in Geophysics (eds) Dmowska $\mathrm{R}$ and Saltzman B (San Diego, USA: Academic Press) 43 1-95.

Panza G F, Romanelli F, Vaccari F, Decanini L and Mollaioli F 2003 Seismic ground motion modelling and damage earthquake scenarios, a bridge between seismologists and seismic engineers; OECD workshop on the relations between seismological DATA and seismic engineering, Istanbul, 16-18 October 2002, NEA/CSNI/R (2003) 1i8, pp. 241-266.

Parvez I A, Vaccari F and Panza G F 2003 A deterministic seismic hazard map of India and adjacent areas; Geophys. J. Int. 155 489-508.

Parvez I A, Vaccari F and Panza G F 2004 Site-specific microzonation study in Delhi metropolitan city by $2-\mathrm{D}$ modeling of SH and P-SV waves; Pure Appl. Geophys. 161(5-6) 1165-1184.

Parvez I A, Vaccari F and Panza G F 2006 Influence of source distance on site-effect in Delhi city; Curr. Sci. 91(6) 827-835.

Salt C A, Alam M M and Hossain M M 1986 Current exploration of the Hinge zone area of southwest Bangladesh; In: Proceedings 6th Offshore SE Asia Conf., 20-31 January 1986 World Trade Centre, Singapore, pp. 65-67.

Seeber L and Armbruster J G 1981 Great detachment earthquakes along the Himalayan arc and long-term forecasting, in earthquake prediction - An international review (eds) Simpson D E and Richards, Maurice Ewing Series 4; The American Geophysical Union, pp. 259-277.

Sengupta A 2000 Instrumentation on Calcutta's metro railway; unpublished report of Metro Railway, Calcutta.

Sengupta S 1966 Geological and geophysical studies in western part of Bengal basin, India; Am. Assoc. Petrol. Geol. Bull. 50 1001-1017.

Som N N 1999 Braced excavation in soft clay - Experiences of Calcutta metro construction, Indian; Geotechnical J. 29(1) 1-87.

Strasser F O and Bommer J J 2009a Large-amplitude ground-motion recordings and their interpretations; Soil Dynam. Earthq. Eng. 29 1305-1329.

Strasser F O and Bommer J J 2009b Review: Strong ground motion - Have we seen the worst?; Bull. Seismol. Soc. Am. 99 2613-2637.

Stuart M 1926 The Srimangal earthquake of 8th July 1918; Geol. Surv. India Memoir 46 1-70. 
Uang C M and Bertero V V 1990 Evaluation of seismic energy in structures; Earthq. Eng. Struct. Dynam. 19 77-90.

Vaccari F, Walling M Y, Mohanty W K, Nath S K, Verma A K, Sengupta A and Panza G F 2011 Site-specific modeling of SH and P-SV waves for microzonation study of Kolkata metropolitan city, India; Pure Appl. Geophys. 168 479-493.

Virieux J 1984 SH-wave propagation in heterogeneous media: Velocity-stress finite-difference method; Geophysics 49 1933-1957.
Virieux J 1986 P-SV wave propagation in heterogeneous media: Velocity-stress finite-difference method; Geophysics $\mathbf{5 1}$ 889-901.

Walling M Y and Mohanty W K 2009 An overview on the seismic zonation and microzonation studies in India; Earth-Sci. Rev. 96 67-91.

Zuccolo E, Vaccari F, Peresan A, Dusi A, Martelli A and Panza G F 2008 Neo-deterministic definition of seismic input for residential seismically isolated buildings; Eng. Geol. 101 89-95. 